\title{
PELAKSANAAN PENGAMBILAN SIDIK JARI DALAM MENGUNGKAP PELAKU TINDAK PIDANA PENCURIAN
}

\author{
I Kadek Aris Setiawan, I Nyoman Gede Sugiarta, Ni Made Sukaryati Karma \\ Fakultas Hukum, Universitas Warmadewa, Denpasar-Bali, Indonesia \\ kadekarissetiawan0698@gmail.com, nyomansugiartha14@gmail.com, madesukaryatikarma@gmail.com
}

\begin{abstract}
Abstrak
Meningkatnya kejahatan pencurian menjadi salah satu keresahan ditengah masyarakat, maka dalam hal ini pelaksanaan pengambilan sidik jari dalam mengungkap tindak pidana pencurian guna mengungkap identitas korban pencurian. Berdasarkan permasalahan tersebut, tujuan penelitian ini untuk menganalisa peranan sidik jari dalam mengungkap tindak pidana pencurian serta proses pengambilan sidik jari di dalam membuktikan pelaku tindak pidana pencurian. Metode penelitian yang digunakan adalah metode penelitian hukum normatif dan empiris. Sumber data yang digunakan yaitu sumber hukum primer dan sekunder. Teknik pengumpulan data dengan wawancara, mencatat, mengutip, membaca, maupun meringkas literatur. Setelah data dikumpulkan, kemudian dianalisis secara kualitatif. Hasil penelitian menunjukkan bahwa peran sidik jari dalam mengungkap tindak pidana pencurian adalah dapat digunakan sebagai alat bukti, dengan menggunakan sistem atau metode identifikasi sidik jari, catatan sidik jari dalam bentuk surat atau keterangan ahli tersebut dapat digunakan sebagai alat bukti tambahan di samping bukti-bukti lain yang ditemukan ditempat kejadian perkara di dalam mengadakan penyidikan.
\end{abstract}

Kata Kunci: Sidik Jari, Pencurian, Pidana.

\begin{abstract}
The increase in the crime of theft has become one of the concerns in the community, so in this case the implementation of fingerprinting in exposing the crime of theft is to reveal the identity of the victim of theft. Based on these problems, the purpose of this research is to analyze the role of fingerprints in uncovering the criminal act of theft and the process of taking fingerprints in proving the perpetrator of the crime of theft. The research method used is normative and empirical legal method. Sources of data used are primary and secondary sources of law. Data collection techniques by interviewing, taking notes, quoting, reading, and summarizing the literature. After the data is collected, it is analyzed qualitatively. The result shows that the role of fingerprints in uncovering criminal acts of theft is that they can be used as evidence, by using a system or method of fingerprint identification, fingerprint records in the form of letters or expert statements can be used as additional evidence in addition to other evidence. found at the scene of the case in conducting an investigation.
\end{abstract}

Keywords: Fingerprint, Theft, Criminal.

\section{PENDAHULUAN}

Seperti yang kita ketahui bahwa persoalan di negara ini terkait pencurian selalu meningkat. Meskipun berbagai upaya telah dilakukan di dalarn memberantas tindak pencurian, tetapi belum menunjukan tanda-tanda penurunan korban pencurian (Prasetyo, 2011). Untuk mengungkap identitas korban pencurian salah satunya adalah dengan sidik jari. Orang sudah mengenal sidik jari dari sejak lama tetapi belum dipergunakan untuk mengungkap kejahatan. Sidikjari belum dimanfaatkan unruk mempermudah atau membantu kehidupan manusia menghadapi suatu kejadian atau peristiwa yang mungkin terjadi. Pemanfaatan sidik jari pada masa sekarang ini tidak hanya dipergunakan untuk pengenalan terhadap identitas seseorang, Aparat Penegak Hukum menggunakan sidik jari untuk penegakan hukum biasanya oleh anggota penjaga keamanan dalam sarana membuat jelas sebuah persoalan pidana.

Tindak Pidana Pencurian sebagaimana diatur didalam Pasal 362-367 KUHP yang berbunyi barang siapa mengambil sesuatu barang, yang seluruhnya atau sebagian kepunyaan orang lain, dengan maksud untuk dimiliki secara melawan hukum, diancam karena pencurian, dengan pidana penjara paling lama lima tahun, ataupun pidana denda paling banyak sembilan ratus rupiah. Setelah terjadinya 
suatu peristiwa kejahatan, maka mengungkap tindak pidana merupakan pekerjaan khusus dari organ penegak hukum (Hamzah, 1986). Guna mengungkap suatu tindak pidana seorang penegak hukum wajib paham bermula dan cara apa penegak hukum mulai kegiatan supaya memperoleh arah yang benar yakni terungkapnya sebuah tindak pidana. Melalui hasil penelitian, sebuah tindak pidana memiliki definisi dimana pelakunya, korban, cara-cara tindak pidana dibuat (modus operandi), konsep tindak pidana serta lain-lain (Gumilang, 1983). Dalam hal ini sidik jari berperan penting dalam mengungkap perkara kejahatan yang terjadi di kalangan masyarakat. Sidik jari seharusnya telah diketahui masyarakat semenjak rentang waktu lama akan tetapi belum digunakan untuk keperluan praktis, artinya maka sidik jari tidak digunakan dengan seluas-luasnya demi mendukung maupun memperlancar kehidupan masyarakat mengalami sebuah kasus insiden yang barangkali berlangsung (Amidjaja, 1984) dalam era saat ini sidikjari dipakai serta dipergunakan bukan sekadar akan pemahaman ulang atas jati diri seseorang, lagipun dipakai bagi Petugas Penegak Hukum dalam bentuk menegakan aturan lazimnya bagi Petugas Penegak Hukum, seraya menjadikan benar sebuah perkara pidana. Meskipun demikian, alat bukti sidik jari tidak bisa menjadi alat bukti tunggal, namun tetap saja sidik jari merupakan bagian dari keterangan yang diberikan oleh ahli yang ditunjuk ketika proses perjalanan sidang perkaranya di pengadilan (Rifai, 2019).

Pada dasarnya fungsi dari sidik jari dalam proses penyidikan yaitu membantu mendapatkan bukti kejahatan di Tempat Kejadian Perkara (TKP). Dalam hal ini, pengambilan sidik jari di TKP merupakan alat bukti petunjuk untuk mengungkap suatu tindak pidana serta pelaku kejahatan (Mardona \& Yenti, 2019). Sidik jari mempunyai kekuatan yang akurat dikarenakan setiap manusia mempunyai sidik jari yang berbeda, tidak dapat diganti atau diubah. Proses pengungkapan tindak kejahatan dengan menggunakan identifikasi sidik jari biasanya disertai keterangan saksi sebagai bahan perbandingan dengan sidik jari di TKP ( $\mathrm{J}$ et al., 2019). Menurut Bachtiar (2014) pengidentifikasian dengan menggunakan sidik jari akan dikembangkan oleh penyidik dalam proses penyelidikan oleh para petugas identifikasi sebagai petunjuk. Lebih lanjut, sidik jari yang ditemukan di TKP dirumuskan sehingga menjadi alat bukti surat dalam bentuk blanko sidik jari.

Berdasarkan uraian diatas, maka tujuan dari penelitian ini untuk menganalisa peranan sidik jari dalam mengungkap tindak pidana pencurian serta proses pengambilan sidik jari di dalam membuktikan pelaku tindak pidana pencurian.

\section{METODE PENELITIAN}

Dalam penelitian ini menggunakan metode hukum yang bersifat hukum normatif dan empiris dengan pendekatan secara normatif dan empiris. Metode hukum normatif menggunakan perundang-undangan yang berlaku, pendekatan konseptual, dan pendekatan kasus, dan literatur yang bersumber dari bahan bacaan, sedangkan empiris, yaitu mengkaitkan dengan kenyataan yang ada dalam permasalahan yang diteliti. Sumber bahan hukum yang digunakan yaitu sumber data hukum primer dimana data diantaranya, (1) data dari Polres Gianyar dan (2) wawancara dengan para informan yaitu Anggota Satuan Lalu Lintas Polres Gianyar, dan anggota ldentifikasi Polres Gianyar, (3) Undang-Undang Dasar Negara Republik Indonesia (UUD NRI 1945), (4) Kitab Undang-Undang Hukum Pidana (KUHP), (5) Undang-Undang Nomor 8 Tahun 1981 Tentang Kitab Undang-undang Hukum Acara Pidana (KUHAP), (6) Undang-Undang Nomor 1 Tahun 1946 Tentang Peraturan Hukum Pidana. Adapun sumber bahan hukum primer bersumber dari pendapat sarjana, pendapat ahli, asas yang disebut dari data yang didapat pada kepustakaan, text book, jurnal hukum, hasil penelitian. Teknik pengumpulan data dilakukan dengan wawancara, mencatat, mengutip, membaca, maupun meringkas literatur yang mengacu terhadap pelaksanaan pengambilan sidik jari dalam mengungkap pelaku tindak pidana pencurian. Setelah data dikumpulkan kemudian dianalisis secara kualitatif.

\section{HASIL DAN PEMBAHASAN}

\section{Peranan Sidik Jari dalam Mengungkap Tindak Pidana Pencurian}

Peranan sidik jari didalam proses penyelidikan untuk mengungkap suatu tindak pidana pencurian yakni demi mempermudah prosedur penyelidikan serta mengungkap pelakunya melalui tahap-tahap yang sudah diatur dalam undang-undang yakni perkara-perkara yang belum pelakunya belum terungkap (perkara gelap). Peran sidik jari dalam menemukan pelaku tindak pidana pencurian di TKP krirninal sering didapatkan barang bukti yang biasa menyokong prosedur penyidikan kasus, contohnya melainkan sidikjari tersangka. Sebab lantaran bukti tubuh yang biasanya didapatkan di 
TKP yakni sidik jari laten yakni bekas tapak jari, telapak tangan, telapak kaki yang tercecer di tekstur objek di TKP sesudah obyek itu,dipegang maupun diinjak.

Maklumat pengusutan sidik jari hanya dapat diberikan kepada hakim demi kepentingan pengadilan, penuntutan serta Aparat Penegak Hukum (Soesilo, 1974) Syarat-syarat pengusutan sidik jari menurut Soesila menyebutkan, yakni

1) Syarat formil yakni dibuat oleh orang yang berwajib, diberikan tanggal serta nomor, dibuat serendah-rendahnya dua (2) orang yang masing-masing menyuguhkan tanda tangan, dibuat atas ikrar jabatan, mengetahui maupun disahkan sama pimpinan.

2) Syarat materil yakni menciptakan informasi tentang prosedur pemeriksaan, menyematkan informasi mengenai sidik jari yang diibaratkan dengan ukuran asli serta yang telah diperbesar lengkap beserta nomor urut demi titik persamaan.

Sesudah sidik jari diproses maka selanjutnya dibandingkan dengan sidik jari orang-orang yang dicurigai yang ada kaitannya dengan tindak kriminal yang berlangsung maupun pelaku tindak pidana yang sudah diproses sidik jarinya. Fungsi membandingkan sidik jari ini dapat menolong penyidik dalam mengungkap tersangka tindak kriminal yang ada.

\section{Proses Pengambilan Sidik Jari dalam Membuktikan Pelaku Tindak Pidana Pencurian}

Proses pengambilan sidik jari dalam membuktikan pelaku tindak pidana pencurian

a) Melalui cara menghampiri TKP (tempat kejadian perkara) sesaat sesudah mendapat laporan.

b) Melaksanakan tindakan pertama di TKP serta melaksanakan pengecekan bagi TKP, yakni menjaga TKP, menghimbau orang-orang yang didapatkan di TKP, demi mengabaikan TKP, seperti saksi, korban, serta orang yang dicurigai, mengamankan barang bukti serta bekas yang didapatkan, Selanjutnya terus dipergunakan pengambilan bagi bekas-bekas tertera seperti tentang jejak sidik jari supaya tidak hilang, terhapus maupun kabur.

c) Melalui taktik mengaplikasikan media rekognisi yang beda, yakni identitas badaniah, air kencing, rambut, serta lainnya, apabila bekas sidik jari yang didapatkan telah tidak memadai untuk digunakan menjadi skema identifikasi maupun bekas sidik jari tertera tak bisa didapatkan dikarenakan lenyap sehingga tidak dapat diidentifikasi.

d) Proses lainnya yakni melalui menambah keterampilan maupun keahlian anggota penegak hukum didalam memakai skema maupun metode identifikasi sidik jari dalam menangani (tempat kejadian perkara) melewati edukasi beserta kursus-kursus secara teratur.

Berdasarkan dari pengertian diatas, maka sidik jari yang didapatkan di TKP memiliki peran yang berarti, guna mengungkap kejahatan (Hamid \& Husein, 2012). Dengan peranannya yang begitu penting tersebut, maka dapat dikatakan begitu besar sekali faedah yang didapatkan oleh aparat penegak hukum didalarn memakai sidik jari ini bak skema demi membikin jelas sebuah tindak kriminal (Tindak Pidana Pencurian). Harun M. Husein, didalam buku yang berjudul Penyidikan dan Penurutan pada Proses Pidana menyebutkan yakni dalam sebuah (tempat kejadian perkara) jelas tersisa sidik jari tersangka, sebab tersangka pada saat melangsungkan aksinya jelas menggunakan tangannya untuk menggenggam objek-objek yang ada (di tempat kejadian perkara). Dalam objekobjek yang disentuh tersisa sidik jari.

Adapun kelemahan-kelemahan pada identifikasi sidik jari, antara lain,

a) Sidik jari mudah lenyap apabila mengenai objek lainnya.

b) Sidik jari bisa menjadi buram maupun rusak jika bertumpang tindih apabila disentuh bagi jari lainnya.

c) Sidik jari tidak akan didapatkan (di tempat kejadian perkara), apabila pelaku memakai pelindung tangan yaitu kantong plastik, kain maupun sarung tangan.

d) Sidik jari yang didapatkan (di tempat kejadian perkara) tak bisa dipakai secara skema maupun teknik identifikasi bilamana berkas Aparat Penegak Hukum belum cukup. Maksudnya kekurangannya ini berlangsung dalam kurun waktu melaksanakan investigasi banding di Laboratorium maupun Unit ldentifikasi celah sidik jari yang berada di Kepolisian.

e) Bilamana kerusakan sidik jari yang didapatkan (di tempat kejadian perkara) terbilang rusak parah maka sidik jari ini tak bisa dipakai secara skema maupun teknik identifikasi demi mendapatkan serta mengenali tersangka kriminal. 


\section{SIMPULAN DAN SARAN}

\section{Simpulan}

Peranan sidik jari dalam mengungkap tindak pidana pencurian adalah dapat digunakan sebagai alat bukti, maksudnya apabila pelaku kejahatan tersebut dapat ditemukan dan diketahui dengan menggunakan sistem atau metode identifikasi sidik jari, catatan sidik jari dalam bentuk surat atau keterangan ahli tersebut dapat digunakan sebagai alat bukti tambahan, di samping bukti lain yang ditemukan di tempat kejadian perkara di dalam rnengadakan penyidikan. Dasar hukum penggunaan sidikjari diatur dalam Pasal 184 KUHAP. Peran sidik jari dalam mengungkap tersangka tindak pidana pencurian di dalam tempat kejadian tindak pidana sering didapatkan barang bukti yang bisa rnembantu prosedur penyidikan perkara terbilang, melainkan sidik jari tersangka. Sebab dari itu salah satu bukti badan yang biasanya didapatkan di tempat kejadian perkara yakni sidik jari laten berupa bekas tapak jari, telapak tangan, telapak kaki yang ditinggalkan di permukaan objek ditempat kejadian perkara sesudah objek itu dipegang maupun diinjak. Adapun proses pengambilan sidik jari dalam mengungkap pelaku tindak pidana pencurian adalah dengan menghampiri tempat kejadian perkara sesudah mendapatkan laporan, melalui proses mempergunakan skema identifikasi, bekerjasama dengan aparat penegak hukum pada saat memakai skema maupun teknik identifikasi sidik jari.

\section{Saran}

Hendaknya masyarakat ikut serta menolong kepolisian dalam menjalankan kewajibannya, yakni dengan cara melapor maupun memberitahukan kejadian sebuah perbuatan kriminal atau Di samping itu juga perlu juga sewaktu-waktu kepolisian melaksanakan aktivitas yakni mengadakan sosialisasi pada masyarakat.

\section{DAFTAR PUSTAKA}

Amidjaja, H. S. (1984). Pedoman Penanganan TKP (Tempat Kejadian Perkara). Jakarta.

Bachtiar, F. I. (2014). Fungsi Alat Bukti (Sidik Jari) dalam Proses Penyidikan Guna Mengungkap Tindak Kejahatan Pencurian (Studi Kasus di Polresta Surakarta). Jurnal Jurisprudence, 4(1), 30-36.

Gumilang, A. (1983). Kriminalistik Pengetahuan tentang Teknik dan Taktik Penyidikan. Angkasa, Jakarta.

Hamid, H., \& Husein, H. M. (2012). Pembahasan Permasalahan KUHAP Bidang Penyidikan (Dalam Bentuk Tanya Jawab). Sinar Grafika, Jakarta.

Hamzah, A. (1986). Pengusutan Perkara Kriminal Melalui Sarana Teknik dan Sarana Hukum. Ghalia Indonesia, Jakarta.

J, M., Syamsuddin, R., \& Asmar, A. R. (2019). Kekuatan Sidik Jari sebagai Alat Bukti Petunjuk dalam Mengungkap Tindak Pidana Pencurian. Alauddin Law Develompent (ALDEV), 1(3), 26-36.

Mardona, R., \& Yenti, N. (2019). Fungsi Sidik Jari dalam Pengungkapan Tindak Pidana Pencurian di Reskrim Polresta Padang. Normative: Jurnal Ilmiah Hukum, 7(2), 1-15.

Prasetyo, T. (2011). Kriminalisasi dalam Hukum Pidana. Nusa Media, Bandung.

Rifai, M. (2019). Kegunaan Sidik Jari dalam Proses Investigasi Perkara Kriminal untuk Mengetahui Identitas Korban dan yang Melakukan Perbuatan Pidana. Syiah Kuala Law Journal, 3(3), 330-347.

Soesilo, R. (1974). Taktik Dan Teknik: Penyidikan Perkara Kriminal. Politea, Bogor. 